MATERNAL AND CHILD HEALTH AROUND THE WORLD 
Related Macmillan Titles

Macmillan Tropical Community Health Manuals

G. J. Ebrahim: Breast Feeding - the biological option

G. J. Ebrahim: Child Care in the Tropics

G. J. Ebrahim: Practical Mother and Child Health in Developing Countries

G. J. Ebrahim: Care of the Newborn in Developing Countries

G. J. Ebrahim: A Handbook of Tropical Paediatrics

D. C. Morley and M. Woodland: See How They Grow - monitoring child growth for appropriate health care in developing countries

I. A. Olatunde: Self Medication: benefits, precautions and dangers

J. Bennett et al.: Community Diagnosis and Health Action - a manual for tropical and rural areas

D. Werner: Where There is No Doctor

G. J. Ebrahim: Paediatric Practice in the Developing World
Macmillan Tropical and Sub-Tropical Medical Texts

M. W. Service: A Guide to Medical Entomology

I. Singh: A Guide to Human Embryology for Medical Students

D. V. T. Swinscow: Statistics at Square One

F. A. Nwako: Paediatric Surgery in the Tropics

J. O. Oluwasanmi: Plastic Surgery in the Tropics an introduction for medical students

A. Adetuyibi: Companion to Clinical Medicine in the Tropics

Macmillan Tropical Nursing and Health Sciences Series

J. A. Akinsanya: Human Biology - a textbook for nurses and allied professions

J. A. Akinsanya: Microbiology - a textbook for nurses and allied professions

V. Ajayi: A Textbook of Midwifery

A. Aarons, H. Hawes and J. Gayton: CHILD-to-child 


\section{MATERNAL AND CHILD HEALTH AROUND THE WORLD}

edited by

Helen M. Wallace, MD, MPH

and

G. J. Ebrahim, FRCP(Ed. and Glas.) DCH(Lond.) 
(c) H. M. Wallace and G. J. Ebrahim, 1981

Softcover reprint of the hardcover 1st edition 1981

All rights reserved. No part of this publication may be reproduced or transmitted, in any form or by any means, without permission.

\section{First Published 1981 by}

THE MACMILLAN PRESS LTD

London and Basingstoke

Associated companies throughout the world.

Typeset in Theme by

STYLESET LIMITED

Salisbury. Wiltshire

\section{British Library Cataloguing in Publication Data}

Maternal and child health around the world.

1. Underdeveloped areas - Family medicine

I. Wallace, Helen M II. Ebrahim, G J

362.1'09172'4 R72.5.G4

ISBN 978-1-349-05388-9 ISBN 978-1-349-05386-5 (eBook)

DOI 10.1007/978-1-349-05386-5

This book is sold subject to the standard conditions of the Net Book Agreement.

The paperback edition of this book is sold subject to the condition that it shall not, by way of trade or otherwise, be lent, re-sold, hired out, or otherwise circulated without the publisher's prior consent in any form of binding other than that in which it is published and without a similar condition including this condition being imposed on the subsequent purchaser. 


\section{Contents}

Notes on Contributors

Preface

\section{Section 1. Introduction}

1. The status of maternal and child care in developing countries.

Franz W. Rosa, MD, MPH

2. World wide problems in the field of maternal and child health and family planning services in the developing countries.

Helen M. Wallace, MD, MPH; Antonio S. Medina, MD, MPH; Donald H. Minkler, $M D, M P H$.

3. Demography and the health situation.

William A. M. Cutting, MRCP, DCH, DObs, FRCOG.

\section{Section 2. Maternal Health}

4. Social background, customs and traditions. Paul C. Y. Chen, MD.

5. Maternity care. K. Bhasker Rao, MD, FAMS.

6. Maternal malnutrition. Leela Raman, MD.

7. Domiciliary midwifery care, including traditional birth attendants.

G. A. Aletor, $M B, B S, M P H, M R C O G$.

\section{Section 3. Family Planning}

8. Family planning. Donald H. Minkler, MD, MPH.

9. Family planning as a part of maternal and child care and general health services.

Franz W. Rosa, MD, MPH.

10. A programme for the integration of family planning with maternal and child health services.

Howard C. Taylor, MD; Robert J. Lapham, PhD, William A. Van Wie, DrPH.

11. The relation of family planning to maternal and child health and paediatrics. J. N. Pohowalla, MD, FRCP, DCH, FAMS. ix

\section{Section 4. Infancy and the Young Child}

13. Growth and development of the infant and young child.

Phyllis B. Eveleth, PhD.

14. Simplified methods of measuring child growth and early nutritional deficiencies. P. M. Shah, MD DCH.

15. Feeding infants and young children. Margaret E. Cameron, BHSC, SRD.

16. The management and prevention of malnutrition.

Nimrod O. Bwibo, MB, ChB, MPH.

17. Protein-energy malnutrition.

K. K. Kaul, MD.

18. Nutrition rehabilitation: an approach to the management and prevention of childhood malnutrition. M. A. Church, MD.

19. Anaemia in mothers and children in developing countries. A. Samy Khalifa, MD.

20. Immunisation. Josephine M. Namboze, MB, BS, MPH.

21. The contribution of common infectious diseases of childhood to malnutrition.

B. N. S. Walia, MD.

22. Common respiratory problems.

$U . \operatorname{Tin} U, M D$.

23. Parasitic diseases.

G. J. Ebrahim, FRCP (Ed. and Glas.) DCH (Lond.).

24. Management and prevention of idiarrhoea. Nimrod O. Bwibo, MB, BS, MPH.

25. The under-fives' clinic.

G. J. Ebrahim, FRCP (Ed. and Glas.) DCH (Lond.).

26. Day care services for the preschool child. Y. C. Mathur, MD, DCH and Ajit Kumar, $M D, D C H$. 
vi Contents

Section 5. The Child of School Age and Adolescence

27. Health services in schools.

Kenneth D. Rogers, $M D$ and Foster $H$. Young, Jr, MD.

28. School health services in developing countries.

M. Nagaraj Rao, MD.

29. Adolescence.

Richard Brown, MD.

Section 6. Handicapped Children and Youth

30. Handicapped children and youth in the United Kingdom.

Kenneth Holt, MD, FRCP, DCH.

31. Blindness due to vitamin A deficiency. Vinodini Reddy, $M D, D C H$.

32. Hearing impairment.

Donald A. Harrington, $P h D$.

Section 7. Social Benefits and Social Welfare Services

33. Identifying and mobilising resources in the village society.

Barbara Demory, PhD.

34. Social security in developing countries. Neil Gilbert, PhD.
Section 8. Special Topics

35. Preparation of the policy makers and planners in the field of maternal and child health and family planning. Helen M. Wallace, MD, MPH.

36. Training programme for teachers in medical schools.

G. J. Ebrahim, FRCP (Ed. and Glas.) DCH (Lond.).

37. Training teachers for health workers. Christopher Wood, MD, FFCM.

38. Village health workers.

G. J. Ebrahim, FRCP (Ed. and Glas.) DCH (Lond.).

39. Community nutrition.

H. J. Leslie Burgess, $M B, C h B, D P H, M S$, MFCM and Ann P. Burgess, BSc, MPH.

40. Social paediatrics. Fred J. W. Miller, MD.

41. Maternal and child health services in the United States.

Helen M. Wallace, MD, MPH.

Section 9. Programmes of Selected International Agencies

42. Family planning and the UNFPA.

A. F. M. Burhanuddin, MD.

43. World population programme assistance. R. T. Ravenholt, MD.

44. The Ford Foundation's interest in maternal and child health. 
Gabriel A. Aletor, MB, BS, MPH, MRCOG.

Consultant obstetrician and gynaecologist; maternal and child health/family planning specialist, senior medical officer of health, Ministry of Health, Benin City, Nigeria.

Richard Brown, MD.

Assistant Professor of Paediatrics in charge of Adolescent Medicine, University of California Medical School, San Francisco General Hospital, San Francisco. Ann P. Burgess, BSc, MPH.

FAO, Rome.

H. J. Burgess, MB, ChB, DTMH, DPH, MS, MFCM. $\mathrm{FAO}$, Rome.

A. F. M. Burhanuddin, MD.

United Nations Fund for Population Activities, New York.

Nimrod O. Bwibo, MB, ChB, MPH.

Professor and head, department of paediatrics, University of Nairobi Medical School, Nairobi, Kenya.

Margaret E. Cameron, MD.

Principal lecturer, nutrition and dietetics, Polytechnic of North London, London, England.

Paul C. Y. Chen, MD.

Professor of social and preventive medicine, Faculty of Medicine, University of Malaya, Kuala Lumpur, Malaysia.

M. A. Church, MD.

Scottish Health Education Unit, 21 Lansdowne Crescent, Edinburgh, Scotland.

William A. M. Cutting, MD, MRCP, DCH, DObsRCOG. Senior lecturer in child life and health, department of child life and health, University of Edinburgh, Scotland.

Barbara Demory, PhD.

Professor of sociology and anthropology, Wilkes College, Wilkes-Barre, Pennsylvania.

G. J. Ebrahim, FRCP (Ed. and Glas.), DCH (Lond.).

Senior lecturer, Tropical Child Health Unit, Institute of Child Health, University of London, London, England.
Phyllis B. Eveleth, PhD.

National Heart, Lung, and Blood Institute, National Institutes of Health, Bethesda, Maryland.

Neil Gilbert, PhD.

Professor, University of California School of Social Welfare, Berkeley.

Oscar Harkavy, PhD.

Officer in charge, population, The Ford Foundation, New York City.

Donald A. Harrington, PhD.

Formerly: Chief, hearing and speech section, division of clinical services, Bureau of Community Health Services, U.S. Department of Health, Education and Welfare. (Present address: 1102 Rolling Acres Drive, Deland, Florida).

Kenneth Holt, MD, FRCP, DCH.

Director, Institute of Child Health, department of developmental paediatrics, University of London.

K. K. Kaul, MD.

Professor and head, department of paediatrics, Smt. Jyotsana Devi Patel Paediatric Center, Government Medical College, Jabalpur, India.

A. Samy Khalifa, MD.

Professor of Paediatrics, Ain Shams Faculty of Medicine, Cairo, Egypt.

Y. C. Mathur, MD, DCH.

Additional professor of social paediatrics, Niloufer Hospital, Hyderabad, India.

Antonio S. Medina, MD, MPH.

Lecturer and research physician in maternal and child health, University of California School of Public Health, Berkeley.

Fred Miller, MD.

Professor Emeritus of Paediatrics, University of Newcastle Medical School, Newcastle-On-Tyne, England.

Donald H. Minkler, MD, MPH.

Lecturer in maternal and child health, University of California School of Public Health, Berkeley, and associate professor of obstetrics and gynaecology, 
University of California Medical School, San Francisco. Josephine M. Namboze, MB, BS, MPH.

Associate professor, Institute of Public Health, Makerere University Medical School, Kampala, Uganda.

J. N. Pohowalla, MD, FRCP, DCH, FAMS.

Emeritus Professor of Paediatrics, MGM Medical College, Indore, India, and advisor in child health, Government of Madhya Pradesh.

Leela Raman, MD.

Assistant director, ICMR. Unit, Vanivilas Hospital, Bangalore, India.

K. Bhasker Rao, MD, FAMS.

Director, Institute of Obstetrics and Gynaecology, Madras, India.

M. Nagaraj Rao, MD.

Assistant professor of paediatric research, Institute of Child Health, Niloufer Hospital, Hyderabad, India.

R. T. Ravenholt, MD.

Director, Office of Population, Bureau for Population and Humanitarian Assistance, U.S. Agency For International Development, Washington, D.C.

Vinodini Reddy, MD, DCH.

National Institute of Nutrition, Hyderabad, India.

Kenneth D. Rogers, MD, MPH.

Professor of Community Medicine, University of
Pittsburgh Medical School, Pittsburgh, Pennsylvania.

Franz W. Rosa, MD, MPH.

Food and Drug Administration, Washington, D.C. Pramilla Senanayake, MBBS, DTPH, PhD.

Medical Programme Adviser International Planned Parenthood Federation, London.

P. M. Shah, MD DCH.

World Health Organization, P.O. Box 374, Mogadishu, Somalia.

Howard C. Taylor, MD.

Director Emeritus, Institute on Human Reproduction, Columbia University, New York, and Senior Consultant, The Population Council.

$U$. Tin U, MD.

Professor of Child Health, Children's Hospital, Rangoon, Burma.

B. N. S. Walia, MD.

Professor of Paediatrics, Postgraduate Institute of Medical Education and Research, Chandigarh, India.

Helen M. Wallace, MD, MPH.

Professor and head, Section on Maternal and Child Health, Graduate School of Public Health, San Diego State University, San Diego, California 92182, USA. Christopher H. Wood, MD, FFCM.

African Medical and Research Foundation, Nairobi, Kenya. 


\section{Preface}

The field of maternal and child health represents one of the areas of basic preventive health services. It has the opportunity and responsibility of promoting optimal health; of protecting the foetus, infant, child and youth during the period of physical and emotional growth and development; of educating parents and children about personal health, disease prevention and child care; of improving nutritional knowledge and nutritional status of mothers and children; of improving the environment in which families live; of making it possible for parents to have the number of children they want and can care for; of preventing handicapping conditions, and of promoting and providing care for handicapped children and other children requiring special care, services and protection.

The field of maternal and child health can have a direct influence on the quality of life of each generation. It can also influence the health and quality of life of the next generation. Thus, it can influence the general condition and strengths of people of any nation.

Mothers and children represent a majority of the people of any country. In developing countries, children under the age of fifteen years represent almost half of the total population. Girls and women of the childbearing age represent one-fifth of the total population. Thus, maternal and child health services, if fully planned, developed, distributed and delivered, should be able to reach two-thirds of the population of developing countries.

Children, youth and their parents represent the most vulnerable part of the population. The foetus from the time of conception and the child from the time of birth are continuously growing, developing and changing. As they do so, their needs change. A knowledge of 'normal' physical and emotional growth and development is essential for those working with children, parents and families. Knowledge and identification of critical periods and high risk situations is also essential; individuals entering or candidates for high risk situations need to be identified early, if the risk and the sequelae are to be prevented or minimised.
Maternal, infant and early childhood mortality rates are high in developing countries, and represent a high proportion of total deaths in these countries. There is a direct correlation between such mortality rates and socioeconomic status. As in more developed countries, the majority of these deaths is preventable through the application of knowledge already available.

Making it possible for parents to have the number of children they want and can care for is an important facet of maternal and child health. It is as important for the couple unable to have any children as it is for the couple likely to have too many or unwanted children, unless education and services are available. Child spacing and pregnancy limitation are important parts of maternal and child health, and are essential if each child is to be wanted and to be reared in a family setting with adequate individual personal care and love. Introducing a new baby into a home where there are already too many children for parents to care for, or where home conditions are hazardous, or when they will lead to abrupt weaning and serious problems of malnutrition and infection can frequently lead to reproductive wastage in the broad sense and to maternal depletion. The protection of children and of child life and health begins with the protection and promotion of maternal health and the facilitation of the desired number of children, child spacing and family size.

According to the World Health Organization (1952),

the object of maternity care is to ensure that every expectant and nursing mother maintains good health, learns the art of child care, has a normal delivery, and bears healthy children. Maternity care in the narrower sense consists in the care of the pregnant woman, her safe delivery, her postnatal examination, the care of her newly born infant, and the maintenance of lactation. In the wider sense, it begins much earlier in measures aimed to promote the health and well-being of the young people who are potential parents, and to 
help them to develop the right approach to family life and to the place of the family in the community. It should also include guidance in parent-craft and in problems associated with infertility and family planning. (1969),

According to the World Health Organisation

the objectives of maternal and child health $(\mathrm{MCH})$ services begin with the immediate heal th problems of mothers and children and extend to health throughout life and to community health. Through concern with child development and the health education of parents and children, the ultimate objective of $\mathrm{MCH}$ services is lifelong health. The effect of careful and informed mothering on the health of the entire family and the relation of family health to community health are important factors in individual, community and national development.

The health of mothers and children is influenced by what happens in and to the family as a whole. The family, in turn, is inevitably affected by the human and environmental conditions of the community whose life it shares. Most $\mathrm{MCH}$ problems are public health and community problems that can be solved only by applying general measures to a whole area.

$\mathrm{MCH}$ is concerned with the biological demands of reproduction, growth and development; with the vulnerability of mothers and children as a result of these demands; and with the special services required. Since injury during development may damage the organism permanently, health measures taken at this stage are potentially of long-term benefit. Recognition of $\mathrm{MCH}$ as an entity is desirable in order to focus concern on the special needs of mothers and children and to mobilize, develop, and organize the services required to meet these needs.

In 1959, the WHO recommended that 'the ideal for which $\mathrm{MCH}$ services should aim is to ensure that every child, wherever possible, lives and grows up in a family unit, with love and security, in healthy surroundings, receives adequate nourishment, health supervision, and efficient medical attention, and is taught the elements of heal thy living'.

The Twenty-first World Health Assembly (WHO, 1969) recognised,

that family planning is viewed by many Member States as an important component of basic health services, particularly of maternal and child health, and in the promotion of family health, and plays a role in social and economic development and that every family should have the opportunity of obtaining information and advice on problems connected with family planning, including fertility and sterility.

The social aspects of obstetrics and gynaecology, as defined by the World Health Organisation (1963) are

those aspects of personal and community life which have an impact on the child-bearing potential, habits, and efficiency of a population and the health and treatment of the individual woman, with particular reference to her reproductive system. Community life is meant to include not only social, economic, and nutritional conditions but also the cultural systems of values, aspirations, and satisfactions that influence marital and family behavior. Under reproductive habits and health are included the factors influencing age at childbirth, family size and spacing, morbidity and mortality of both mother and child and the appropriate organization of maternity, gynaecological and medico-social services.

The purpose of this book is to share and disseminate information provided by experts in the field of maternal and child health around the world to health workers in the field of $\mathrm{MCH}$ and to students, in the hope that the health care of mothers and children will improve.

Helen M. Wallace, MD, MPH

G. J. Ebrahim, FRCP (Ed. and Glas.) DCH (Lond.).

\section{REFERENCES}

World Health Organization (1952). Expert committee on maternity care. Technical Report Series No. 51. Geneva, Switzerland.

WHO (1959). Administration of maternal and child health services. Technical Report Series No. 115. Geneva, Switzerland.

WHO (1963). Social Aspects in the teaching of obstetrics and gynaecology. Technical Report Series No. 266. Geneva, Switzerland.

WHO (1969). The organization and administration of maternal and child health services. Technical Report Series No. 428. Geneva, Switzerland. 